\title{
Effect of Agri-horti Systems and Weed Management Practices on Growth and Yield of Finger Millet (Eleusine coracana $\mathrm{L}$.)
}

\author{
Lokendra Batham ${ }^{1 *}$, Manoj Kumar Singh ${ }^{1}$, Ashutosh yadav', \\ Sudhir Das ${ }^{2}$ and Sarvesh Kumar ${ }^{3}$
}

${ }^{1}$ Department of Agronomy, Institute of Agricultural Sciences, Banaras Hindu University, Varanasi, Uttar Pradesh, India-221005

${ }^{2}$ Department of Horticulture, Department of Soil Science, ${ }^{3}$ Regional Research Sub-Station, Dr.Rajendra Prasad Central Agricultural University, Pusa, Bihar, India-848125

*Corresponding author

\section{A B S T R A C T}

Keywords

Agri-horti system,

Finger millet,

Herbicide and weed management

Article Info

Accepted:

14 June 2020

Available Online:

10 July 2020
Afield experiment was conducted during the kharif (rainy) season of 2018 at Agricultural Research Farm, Banaras Hindu University-South Campusin Eastern Uttar Pradesh of district Mirzapur in split plot design replicated thrice. The main factor consist of three agri-horti system i.e. [guava (Psidium guajava), bael (Aegle marmelos) and open field] while 6-weed management practices sub factor[2-HW (20 \& 40 DAS), Oxyflourfen 0.1 $\mathrm{kg}$ a.i./ha (PE) fbclodinafop 60g a.i/ha (PoE), bispyribac-Na $20 \mathrm{~g}$ a.i./ha (early PoE), isoproturon $0.75 \mathrm{~kg}$ a.i /ha (PE) fb1-hand-weeding (30 DAS), pendimethalin $1.0 \mathrm{~kg}$ a.i./ha fbquizalofop-ethyl $0.04 \mathrm{~kg} / \mathrm{ha}, 2-\mathrm{HW}(20 \& 40$ DAS) and weedy check]. Application of 2-HW (20 \& 40 DAS) and isoproturon $0.75 \mathrm{~kg} / \mathrm{ha}$ (PE) $f b 1-\mathrm{HW}$ (30 DAS) effectively manage the weeds vis-à-vis produced higher crop growth, yield attributes and yield of finger millet followed by oxyflourfen $0.1 \mathrm{~kg} / \mathrm{ha}(\mathrm{PE}) \mathrm{fb}$ clodinafop $60 \mathrm{~g} / \mathrm{ha}$ (PoE), bispyribac - Na $20 \mathrm{~g} / \mathrm{ha}(\mathrm{PoE})(15 \mathrm{DAS})$, pendimethalin $1.0 \mathrm{~kg} / \mathrm{ha}$ (PE) $f b$ quizalofop-ethyl $0.04 \mathrm{~kg} / \mathrm{ha}(\mathrm{PoE})$.

\section{Introduction}

Finger millet is an important minor millet that is cultivated in India. It is a staple food crop in many of the country's hilly areas. This crop is grown at an altitude of 2100 meters above sea level. It is, in reality, the primary cereal crop for monsoon season in some hill region. It is cultivated for both grain and forage. In northern hills, grains are eaten mostly in the form of, chapattis, in south India grain are used in many preparations like cakes, 
puddings, sweets. Mandua grain contains 9.2 $\%$ protein, $1.29 \%, 76.32 \%$ carbohydrate, $2.24 \%$ minerals, $3.90 \%$ ash and $0.33 \%$ calcium. It is good for persons suffering from diabetes. It is cultivated over an area of 2.65 million hectares with total production of about 2.9 million tonnes (Singh et al., 2003).Finger millet is grown largely as drill sown crop under rainfed conditions and as transplanted crop under irrigation. Since, the crop has slow growth habit in the initial stages, the weeds possessing faster growth habit can avail of this situation and offer severe competition to the crop for light, nutrients and moisture (Kumar et al., 2015) and (Ramachandra Prasad et al., 1991 and Singh and Arya, 1999) found the critical period of weed competition in finger millet to be around 30 to 45 days after sowing and further delay in weed control leads to serious decrease in grain yield ranging from 34 to 61percent.Manual weeding (2-3), common practices for weed management in finger millet. Herbicides have been reported to be effective and economically feasible in the smallholder (Muoni et al., 2013).

India's population is growing rapidly, while the size of an average farm holding is shrinking (Srinivasa Rao et al., 2014). Now-adays, it is a biggest challenge for a country to feed the burgeoning population, that too without horizontal expansion in land holding. In fact, in near future, in India the demand of cereals is projected to grow from current production of 261.8 million tons (FAO 2019) to 270 million tons in 2024-2025 (Srinivasa Rao et al., 2014). Therefore, one of the ways for increasing the production of cereals is the utilization of inter-row spaces under agroforestry system for the introduction of annual cereals crops. Among the various categories of agro-forestry system, agri-horti system is most popular among the farmers, where the annual crops are grown simultaneously in the alley of the fruit-tree (Lundgren and Raintree, 1982; Nair, 1993).
The mechanical and cultural methods of weed control are no doubt effective; however, nonavailability of labour and ever increasing labour cost due to rapid urbanization and industrialization farmers many a time experience severe labour shortage. Coupled with ever increasing cost of labour, it is uneconomical and difficult to employ these methods to control weeds was reported by Fischer et al., (2001). The use of herbicides in controlling weeds has been proved successful in the advanced countries and is now gaining ground in Indian Agriculture, in view of labour scarcity and prohibitive wages. Under these situations the herbicides play an important role in weed management. However, it is essentially required that before introduction of any crop in between the alleys of agri-horti system it is utmost important to work out the compatibility of component species (annual crop and perennial tree), because many a time, due to negative interactions between the component species, the growth and yield of annual crop was seriously affected (Thapaliyal et al., 2008).

Agroforestry has the potential to create a more integrated, diverse, productive, profitable, healthy, and sustainable land-use system (Sharma et al., 2017). However, it is essentially required that before introduction of any crop in between the alleys of agri-horti system it is utmost important to work out the compatibility of component species (annual crop and perennial tree), because many a time, due to negative interactions between the component species, the growth and yield of annual crop was seriously affected (Thapaliyal et al., 2008). Since, the crop has slow growth habit in the initial stages, the weeds possessing faster growth habit can avail of this situation and offer severe competition to the crop for light, nutrients and moisture (Kumar et al., 2015) and (Prasad et al., 1991 and Singh and Arya, 1999) found the critical period of weed competition in finger millet to be around 30 to 45 days after 
sowing and further delay in weed control leads to serious decrease in grain yield ranging from 34 to 61 percent. It was observed that species combinations and importance of weed communities differ with agroforestry system because; some studies have documented inhibitory allelopathic effects of trees on weed germination and growth (Kaur et al., 2011). Therefore, one of the ways for increasing the production of cereals is the utilization of inter-row spaces under agroforestry system for the introduction of annual cereals crops. Among the various categories of agro-forestry system, agri-horti system is most popular among the farmers, where the annual crops are grown simultaneously in the alley of the fruit-tree (Lundgren and Raintree 1982, Nair 1993). This system not only helps in better utilization of land resources but also generates more employments and income as compared to sole cultivation of fruit trees. Actually, during the initial 6-7 years of agri-horti systems and even after that period, with proper pruning management, intercrop annual crops in agrihorti system produce good yield, without any significantly reduction (Kumar 2018).

Therefore, under the agro-climatic conditions of Vindhyan zone, there is good opportunity to introduce some millets as inter-crop in the alleys of agri-horti system. Millets are the most viable option in the dryland conditions as they require minimum water and can with stand in the adverse weather conditions (Chapke et al., 2018) and can usher in food, feed, fodder, nutritional and livelihood security of the farmers. In fact, millet as also called as "Miracle Nutri-Cereals" providing nutritional and health security to all in dry land ecosystems. Among the various small millet grown in India, finger millet contributes nearly $80 \%$ of production and the remaining from kodo millet, little millet, foxtail millet, barnyard millet and proso millet in that order (IIMR, 2015).

\section{Materials and Methods}

\section{Experimental site and soil}

A field experiment was conducted during the kharif (rainy) season of Agricultural Research Farm, Banaras Hindu University-South Campus, $25^{\circ} 10^{\prime}$ latitude, $82^{\circ} 37^{\prime}$ longitude and an altitude of 147 meters above mean sea level, Mirzapur, Uttar Pradesh. The experimental field soil was sandy clay loam in texture, classified as Inceptisol (Typic Ustochrept), having slightly acidic ( $\mathrm{pH}$ 5.76.4 ), low in nitrogen and organic carbon $(0.29 \%)$ whereas, medium in available $\mathrm{P}$ and $\mathrm{K}$ contents. The total rainfall received during crop season i.e. august to November growing period was $455.6 \mathrm{~mm}$, out of which nearly 50 percent receive September.

\section{Trial establishment}

In split plot design, experiment was conducted involving three agri-horticultural system i.e. guava (Psidium guajava), bael (Aeglemarmelos) and open field in main plot and 6-weed management practices [Oxyflourfen $0.1 \mathrm{~kg}$ a.i./ha (PE)fbclodinafop $60 \mathrm{~g}$ a.i/ha $(\mathrm{PoE})$, bispyribac-Na $20 \mathrm{~g}$ a.i./ha (early PoE), isoproturon0.75 $\mathrm{kg}$ a.i /ha (PE) fb1-hand-weeding (30 DAS), pendimethalin $1.0 \mathrm{~kg}$ a.i./ha fbquizalofop-ethyl $0.04 \mathrm{~kg} / \mathrm{ha}$, 2-HW (20 \& 40 DAS) and weedy check] were randomly allocated to subplots and replication three. Seed of finger millet (variety: VL Mandua 352) was sown at the rate of $6-8 \mathrm{~kg} / \mathrm{ha}$ at $10 \mathrm{~cm}$ depth in open furrows made with a manual single row drill, having a row spacing of $23 \times 10 \mathrm{~cm}$ and immediately covered with soil(Singh et al., 2003).Crop was uniformly fertilized with urea, and DAP to supply $40 \mathrm{kgN} / \mathrm{ha}$ and $40 \mathrm{~kg}$ $\mathrm{P}_{2} \mathrm{O}_{5} /$ ha, respectively. Pre-emergence (PE) herbicide applied within 2-day of sowing, whereas, early post emergence (PoE) and $\mathrm{PoE}$ was applied 20 and 30 DAS, respectively. 
Before spraying, herbicides were dissolved in water at the rate of $500 \mathrm{~L} / \mathrm{ha}$ and sprayed with a knapsack sprayer fitted with a flat-fan nozzle.

\section{Biometrical observations}

Various yield and straw yield parameters such grain yield (kg/ha), straw yield ( $\mathrm{kg} / \mathrm{ha})$, biological yield, harvest index and total cost of cultivation, net return and gross return parameter were recorded. Weed density and biomass were recorded at $60 \mathrm{DAS}$, as per the procedure given by Singh and Saini (2008) as presented as number $/ \mathrm{m}^{2}$ and $\mathrm{g} / \mathrm{m}^{2}$, respectively. For estimation nitrogen $(\mathrm{N})$, phosphorus (P) and potassium (K) uptake by green gram and weeds, first $\mathrm{N}, \mathrm{P}$, and $\mathrm{K}$ content in plant samples were determined. Nitrogen content in plant samples (crop and weeds) were estimated by micro-Kjeldahl method.

However, phosphorus was estimated colorimetrically following the vanadomolybdate method and potassium content in the aliquot of the triple acid extract was estimated by emission spectrophotometry using EEL flame photometer (Jackson, 1973).

\section{Statistical analysis}

Data collected on crop and weed growth statistically analysed as per procedure suggested by Gomez and Gomez, 1984. Heterogeneous weed (density and biomass) data were square-root transformed prior to analysis to produce a near normal distribution, although non transformed means are presented for clarity.

The treatment differences were tested by ' $F$ ' test of significance on the basis of null hypothesis. Critical differences were worked out at 5 per cent level of probability where ' $F$ ' test was significant.

\section{Results and Discussion}

\section{Effect on weed growth}

Data presented in table-3 showed that three agri-hortisystem is similar above the ground morphology (i.e tree height, canopy diameter, number of branches, crown length and girth). Most of the yield and economics parameter are non-significantly influenced with the agri-horti system. Further, open field showed lowest infestation of BLWs. The reasons for increased growth and yield parameters under open field might be due to several reasons, firstly, finger millet being a C4 crop for higher photosynthetic efficiency requires full sunlight for light saturation. It is hypothesized that under the alley cropping system, inter-row finger millet crop received reduced light due to shading effect of tress plantation, which would ultimately reduce the crop yield. Similarly, Reynolds et al., (2007) also in view that the degree of light reduction from the agro-forestry tree species would depend on the tree species, it's shape, height of crown and density of foliage. Further, they observed that $\mathrm{C} 4$ understorey crop produced low yield due to reduced availability of light. Secondly, under open field condition due to higher light intensity there might be more uptake of nutrients due to enhanced activity of AM fungi, which may positively affect the various growth and yield parameters. Similarly, Shukla et al., (2008) tested the growth response of different crops u0nder variable light intensity along with AM inoculation and results showed that the activity of AM fungi normally enhanced with higher light intensity (100 per cent) as compared to the low light intensity, which in turn increase the P-uptake by the plant. Thirdly, researches showed that many a time agro-forestry system exhibited negative allelopathic interactions which would adversely affect the crop growth and yield, however, these allelopathic interactions are absent under the open field situation (Thapaliyal et al., 2008), thus results in higher yield. 
Table.1 Influences of weed management practices on grain yield, straw yield and economic of finger millet

\begin{tabular}{|c|c|c|c|c|c|c|c|c|}
\hline \multirow[t]{2}{*}{ Treatment } & \multicolumn{3}{|c|}{ Yield (kg/ha) } & \multirow[t]{2}{*}{ Harvest Index } & \multicolumn{4}{|c|}{ Economics } \\
\hline & Grain & Straw & Biological & & $\begin{array}{c}\text { Total cost of cultivation } \\
\text { () }\end{array}$ & $\begin{array}{c}\text { Gross return } \\
(())\end{array}$ & $\begin{array}{c}\text { Net return } \\
\text { () }\end{array}$ & B:C ratio \\
\hline \multicolumn{9}{|c|}{ Agri-horti system } \\
\hline Guava & $2901.23 b$ & $5056.58 \mathrm{a}$ & $7957.81 \mathrm{~b}$ & $36.48 b$ & 48454.43 & 205564.14 & 157109.71 & 4.24 \\
\hline Bael & $2831.33 c$ & $3672.84 \mathrm{~b}$ & $6504.17 \mathrm{c}$ & $43.40 \mathrm{a}$ & 48981.82 & 195609.81 & 146628.00 & 3.99 \\
\hline Open field & $3679.48 \mathrm{a}$ & $4891.98 \mathrm{a}$ & $8571.46 \mathrm{a}$ & $43.60 \mathrm{a}$ & 22691.77 & 114924.73 & 92232.96 & 5.06 \\
\hline SEm \pm & 40.44 & 78.07 & 118.51 & 0.67 & - & - & - & - \\
\hline $\mathrm{CD}(\mathbf{P}=\mathbf{0 . 0 5})$ & 158.79 & 306.54 & 465.33 & 2.65 & - & - & - & - \\
\hline \multicolumn{9}{|c|}{ Weed management practice $(\mathrm{W})$} \\
\hline Oxy $f b$ Clod & $3101.85 b$ & $4351.85 b$ & $7453.70 c$ & $41.89 \mathrm{a}$ & 114459.0 & 512713.52 & 398254.51 & 4.48 \\
\hline Bis-Na & $3306.28 b$ & $4526.75 b$ & $7833.03 c$ & $42.28 \mathrm{a}$ & 112682.7 & 531298.57 & 418615.86 & 4.71 \\
\hline IPfb 1-HW & $3522.02 \mathrm{a}$ & $5318.93 a$ & $8840.95 b$ & $40.04 a$ & 127232.7 & 551495.40 & 424262.69 & 4.33 \\
\hline PendifbQuiza & $2802.16 b$ & $3899.18 \mathrm{c}$ & $6701.34 d$ & $41.88 \mathrm{a}$ & 118948.7 & 485288.62 & 366340.41 & 4.08 \\
\hline 2-HW & $3786.01 \mathrm{a}$ & $5833.33 a$ & $9619.34 \mathrm{a}$ & $39.78 \mathrm{a}$ & 136772.7 & 575769.08 & 438996.37 & 4.21 \\
\hline WC & $2305.77 \mathrm{c}$ & $3312.76 \mathrm{~d}$ & $5618.53 \mathrm{e}$ & $41.09 \mathrm{a}$ & 110672.7 & 440026.87 & 329354.16 & 3.98 \\
\hline SEm \pm & 123.15 & 139.62 & 262.77 & 1.25 & - & - & - & - \\
\hline $\mathrm{CD}(\mathrm{P}=\mathbf{0 . 0 5})$ & 355.68 & 403.24 & 758.92 & 3.62 & - & - & - & - \\
\hline $\mathbf{S} * \mathbf{W}$ & $\mathrm{S}$ & $\mathrm{S}$ & $\mathrm{S}$ & $\mathrm{S}$ & - & - & - & - \\
\hline
\end{tabular}


Table.2 Effect of agri-horti system and weed management practices on density and biomass grasses and BLWs in finger millet

\begin{tabular}{|c|c|c|c|c|c|c|c|c|}
\hline \multirow[t]{3}{*}{ Treatment } & \multicolumn{2}{|c|}{ Acalypha indica } & \multicolumn{2}{|c|}{ Oldenlandia corymbosa } & \multicolumn{2}{|c|}{ Eclipta alba } & \multicolumn{2}{|c|}{ Anagallis arvensis } \\
\hline & $\begin{array}{c}\text { Density } \\
\left(\text { plant } / \mathrm{m}^{2}\right)\end{array}$ & $\begin{array}{c}\text { Biomass } \\
\left(\mathrm{g} / \mathrm{m}^{2}\right)\end{array}$ & $\begin{array}{c}\text { Density } \\
\left(\text { plant } / \mathrm{m}^{2}\right)\end{array}$ & $\begin{array}{c}\text { Biomass } \\
\left(\mathrm{g} / \mathrm{m}^{2}\right)\end{array}$ & $\begin{array}{c}\text { Density } \\
\left(\text { plant } / \mathrm{m}^{2}\right)\end{array}$ & $\begin{array}{c}\text { Biomass } \\
\left(\mathrm{g} / \mathrm{m}^{2}\right)\end{array}$ & $\begin{array}{c}\text { Density } \\
\left(\text { plant } / \mathrm{m}^{2}\right)\end{array}$ & $\begin{array}{c}\text { Biomass } \\
\left(\mathrm{g} / \mathrm{m}^{2}\right)\end{array}$ \\
\hline & 45 DAS & 45 DAS & 45 DAS & 45 DAS & 45 DAS & 45 DAS & 45 DAS & 45 DAS \\
\hline \multicolumn{9}{|l|}{$\begin{array}{l}\text { Agri-horti } \\
\text { system }\end{array}$} \\
\hline Guava & 2.68(8.89)a & $2.96(11.56) a$ & $3.89(22.78) a$ & $3.86(22.19) \mathrm{a}$ & $2.46(9.72) b$ & $2.57(10.57) a$ & $3.42(14.72) \mathrm{a}$ & 4.10(21.89)a \\
\hline Bael & $0.71(0.00) b$ & $0.71(0.00) \mathrm{c}$ & $0.71(0.00) b$ & $0.71(0.00) \mathrm{b}$ & $0.71(0.00) \mathrm{c}$ & $0.71(0.00) b$ & $2.99(12.50) b$ & $3.52(18.85) b$ \\
\hline Open field & $1.96(5.28) \mathrm{a}$ & $1.89(0.07) b$ & $3.77(22.22) \mathrm{a}$ & $3.87(24.16) \mathrm{a}$ & $\begin{array}{c}3.23(15.28) \\
\mathrm{a}\end{array}$ & $3.17(15.61) \mathrm{a}$ & $0.71(0.00)) \mathrm{c}$ & $0.71(0.00) \mathrm{c}$ \\
\hline SEm \pm & 0.27 & 0.19 & 0.40 & 0.35 & 0.17 & 0.18 & 0.06 & 0.08 \\
\hline $\mathrm{CD}(\mathrm{P}=\mathbf{0 . 0 5})$ & 1.06 & 0.75 & 1.57 & 1.37 & 0.68 & 0.70 & 0.22 & 0.30 \\
\hline \multicolumn{9}{|c|}{ Weed management practices(w) } \\
\hline Oxy fb Clod & $1.45(2.78) b$ & $1.61(3.81) b$ & $3.25(18.33) b$ & $3.13(16.74) b$ & $1.49(3.89) \mathrm{b}$ & $1.61(4.99) b$ & $2.78(11.11) \mathrm{a}$ & $3.45(18.04) \mathrm{a}$ \\
\hline Bis-Na & $2.19(6.67) \mathrm{a}$ & $1.78(4.34) b$ & $3.19(15.00) b$ & $3.22(15.34) b$ & $2.46(9.44) b$ & $2.55(10.25) \mathrm{b}$ & $2.44(9.44) b$ & $2.83(13.54) b$ \\
\hline IPfb 1-HW & $1.27(2.22) \mathrm{b}$ & $1.28(2.29) \mathrm{c}$ & $1.07(1.67) \mathrm{c}$ & $0.97(0.39) \mathrm{c}$ & $0.99(1.11) \mathrm{c}$ & $1.04(1.25) \mathrm{c}$ & $2.40(7.78) b$ & $2.69(10.46) b$ \\
\hline $\begin{array}{l}\text { Pendifb } \\
\text { Quiza }\end{array}$ & $2.19(6.11) \mathrm{a}$ & $2.29(7.06) \mathrm{b}$ & $3.23(15.56) b$ & $3.44(18.69) b$ & $\begin{array}{c}3.00(12.78) \\
\mathrm{b}\end{array}$ & $3.10(13.67) \mathrm{a}$ & $1.77(5.00) \mathrm{b}$ & $2.05(7.45) b$ \\
\hline 2-HW & $0.71(0.00) b$ & $0.71(0.00) c$ & $0.71(0.00) c$ & $0.71(0.00) \mathrm{c}$ & $0.71(0.00) \mathrm{c}$ & $0.71(0.00) \mathrm{c}$ & $0.89(0.56) \mathrm{c}$ & $0.78(0.16) c$ \\
\hline WC & $2.89(10.56) a$ & $3.46(15.73) \mathrm{a}$ & $5.28(39.44) \mathrm{a}$ & $5.41(40.93) \mathrm{a}$ & $\begin{array}{c}4.15(22.78) \\
a\end{array}$ & $4.08(21.91) \mathrm{a}$ & $3.95(20.56) a$ & $4.85(31.83) \mathrm{a}$ \\
\hline SEm \pm & 0.28 & 0.32 & 0.54 & 0.56 & 0.36 & 0.42 & 0.41 & 0.50 \\
\hline $\mathrm{CD}(\mathrm{P}=\mathbf{0 . 0 5})$ & 0.81 & 0.94 & 1.55 & 1.62 & 1.05 & 1.20 & 1.19 & 1.45 \\
\hline $\mathbf{S} * \mathbf{W}$ & $\mathrm{S}$ & $\mathrm{S}$ & $\mathrm{S}$ & $\mathrm{S}$ & $\mathrm{S}$ & $\mathrm{S}$ & $\mathrm{S}$ & $\mathrm{S}$ \\
\hline \multicolumn{9}{|c|}{ 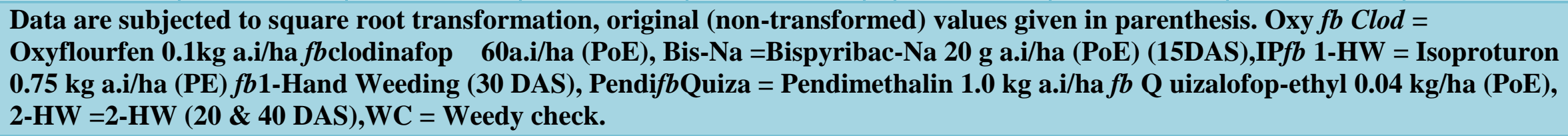 } \\
\hline
\end{tabular}


Table.3 Biometrical observation of guava and bael plantation

\begin{tabular}{|c|c|c|c|c|c|c|c|c|}
\hline \multicolumn{9}{|c|}{ Guava field plantation } \\
\hline \multicolumn{3}{|c|}{ Plant Height (m) } & \multicolumn{2}{|c|}{ Canopy diameter $(\mathrm{m})$} & \multicolumn{2}{|l|}{ Crown length (m) } & \multicolumn{2}{|l|}{ Girth (m) } \\
\hline & $\begin{array}{l}\text { At time of } \\
\text { sowing of } \\
\text { finger millet }^{\mathrm{a}}\end{array}$ & $\begin{array}{l}\text { At harvest of } \\
\text { finger millet }^{b}\end{array}$ & $\begin{array}{l}\text { At time of } \\
\text { sowing of } \\
\text { finger millet }^{\mathrm{a}}\end{array}$ & $\begin{array}{l}\text { At harvest of } \\
\text { finger millet }^{b}\end{array}$ & $\begin{array}{l}\text { At time of sowing } \\
\text { of finger millet }^{\mathrm{a}}\end{array}$ & $\begin{array}{l}\text { At harvest of } \\
\text { finger millet }^{\mathrm{b}}\end{array}$ & $\begin{array}{l}\text { At time of } \\
\text { sowing of } \\
\text { finger millet }^{\mathrm{a}}\end{array}$ & $\begin{array}{l}\text { At harvest of } \\
\text { finger millet }^{b}\end{array}$ \\
\hline Mean & 4.31 & 4.48 & 4.78 & 4.95 & 3.86 & 3.97 & 0.35 & 0.36 \\
\hline Range & $3.68-4.87$ & $3.75-4.95$ & $4.26-5.48$ & $4.96-6.09$ & $3.35-5.54$ & $3.48-4.39$ & $0.35-0.37$ & $0.35-0.38$ \\
\hline SD & 0.32 & 0.34 & 0.38 & 0.39 & 0.28 & 0.29 & 0.086 & 0.086 \\
\hline \multicolumn{9}{|c|}{ Bael field plantation } \\
\hline Mean & 6.61 & 6.82 & 7.50 & 7.72 & 5.55 & 5.67 & 0.55 & 0.56 \\
\hline Range & $6.09-7.01$ & $6.24-7.50$ & $6.78-5.58$ & $7.0-8.05$ & $4.87-6.01$ & $5.02-6.24$ & $0.55-0.59$ & $0.57-0.61$ \\
\hline SD & 0.21 & 0.25 & 0.33 & 0.36 & 0.37 & 0.37 & 0.03 & 0.03 \\
\hline
\end{tabular}

a: Observation recorded on 12.09.2018, b: Observation recorded on 12.11.2018. 
Fourthly, as per Burman et al., (2009)and Anusha et al., (2015) sole crop grown under open field condition not only have less competition for light but also for the moisture, as compared to intercrops in association with different tree spacing. This might be one of the prime reasons for reduced yield under agro-forestry system.

Previous study conducted by Rahangdale et al., (2014) also recorded higher growth and yield attributing characters of different crops like, mungbean, soybean, paddy and till in the open condition as compared to bamboo based agrisilviculture system. These results are in conformity with the findings of Handa et al., (1995), Bihari (2001), Shanmughavel and Francis (2001) and Ahlawat et al., (2008). Previous experiment conducted in kharif season under similar location also showed the higher crop growth and yield attributes of cowpea in open-field condition as compare to guava and custard apple-agri-horti system (Kumar, 2019). Secondly, guava plantation releases certain allelochemicals in root rhizosphere which are responsible for selective inhibition of weed flora under guava plantations (Kawawa et al., 2016, Chapla and Campos 2010 and Thapaliyal et al., 2008).

Furthermore, after the open-field condition, the highest growth, yield attributes and yield of finger millet was observed under guava agri-horti system over bael agri-horti system. Actually, in bael agri-horti system due to higher canopy diameter and crown length there was more shading effect on the finger millet, thus the performance of the crop was adversely affected (Elizabeth et al., 1990).

On the basis of the investigation, it can now be concluded that under eastern Uttar Pradesh, finger millet under guava based agrihorti system showed highest gross return and net return of combined economics (finger millet+fruit) as well as followed by bael based agri-horti system and open field. However, open field condition recorded the highest profit (B:C ratio) among the agro-forestry treatment tested. Moreover, bael based agrohorti system effectively suppressed the weeds, particularly critical period of cropweed competition and enhance the yield of finger millet followed by guava based agrihorti system and open field.

Application of 2-HW (20 \& 40 DAS) and isoproturon $0.75 \mathrm{~kg} / \mathrm{ha}(\mathrm{PE})$ bf 1 - HW (30 DAS) $\left(\mathrm{W}_{3}\right)$ effectively manage the weeds visà-vis produced higher crop growth, yield attributes and yield of finger millet. Although, 2-handweeding (45 \& 60 DAS) have the higher weed suppression (WCE 92.91), crop growth and yield $(3786.01 \mathrm{~kg} / \mathrm{ha})$ of finger millet, however, under labours scarcity, application of isoproturon $0.75 \mathrm{~kg} / \mathrm{ha}$ (PE) bf 1- HW (30 DAS)also gave comparable weed smothering (WCE 80.56) and enhanced yield attributes and yield $(3522.02 \mathrm{~kg} / \mathrm{ha})$ of finger millet.

\section{References}

Ahlawat IPS, and Shivakumar BG, kharif pulses, In Textbook of field crop production. Dr. R. Prasad (Ed.). New Delhi: Indian Council of Agriculture Research, 2005.

Anusha S, Nagaraju, Mallikarjuna GB, Bhaskar V, Gururajkombali AND Vishwanath BR, Performance of finger millet (Eleusine coracana (L.)Gaertn) in association with different MPTs in agroforestry system, Indian Journal of Agroforestry, 17 (2), 82-85, 2015

Burman D, Gill AS, Baig MJ, And Prasad, $\mathrm{JV}$, Interaction between Dalbergiasissoo boundary planting and food- fodder crop sequence under rainfed agroecosystem, Indian Journal of Dryland Agriculture Research and Development, 24 (1), 67-74 2009. 
Chapla TE and Campos JB, Allelopathic evidence in exotic guava (Psidium guajavaL.), Brazilian Archives Biology and Technology, 53 (6), 1359-1362, 2010.

Chapke RR, Prabhakar G, Prasad SIK, Das VA. Tonapi, Improved millets production technologies and their impact, ICAR-Indian Institute of Millets Research, Hyderabad, India, 2018.

A. Pierson, Richard N, Mack and Black RA, The effect of shading on photosynthesis, growth, and regrowth following defoliation for Bromus tectorum, Ecologia, 84, 534-543, 1990.

FAO, Crop prospects and food situationquarterly global. Food and Agriculture Organization of the United Nation report, 2019.

Gomez KA and Gomez AA, Statistical Procedures in Agriculture Research, Wiley $2^{\text {nd }}$ Edition, New York, Chichester, 1984.

Handa SS, Chawla AS Sharma, AK, Plants with antiinflammatory activity,

Fitoterapia, 63, 3-31, 1995

IIMR, Annual report-Indian Institute of Millets Research (IIMR), ISSN-09726608,Hyderabad, India, 2015.

Jackson ML, Soil Chemical Analysis, Englewood Cliffs, NJ: Prentice Hall, 1958.

Kaur S, Singh HP, Batish DR and Kohli RK, Chemical characterization and allelopathic potential of volatile oil of Eucalyptus tereticornis against Amaranthus viridis, Journal of Plant Interactions, 6, 297-302, 2011.

Kawawa RCA, Obiri JF, Muyekho FN, Omayio DO, Agevi H, Mwaura A, Obiet L, Kimutai DK, and Sifuna AW, Allellopathic potential of invasive Psidium guajava L., Against selected native tree species in Kakamega Tropical Forest, Western Kenya, Journal of Pharmacy and Biological
Sciences, 11 ,80-86, 2016.

Kumar PMK, Shekara BG, Sunil CM, and Yamuna BG, Response of drill sown finger millet [Eleusine coracana $\mathrm{L}$.] to pre and post emergence herbicides, An International Quarterly Journal of Life Science, 10 (1), 299-302, 2015.

Kumar PMK, Shekara BG, Sunil CM, and Yamuna BG, Response of drill sown finger millet [Eleusine coracana $\mathrm{L}$.] to pre and post emergence herbicides, An International Quarterly Journal of Life Science, 10 (1), 299-302, 2015

Lundgren BO and Raintree JB, Sustainable agroforestry, In: Agricultural Research for development- Potential and Challenges in Asia (Nestel B ed.), International Service for National Agriculture Research, Den Haag, Netherlands, 1982.

Muoni T, Rusinamhodzi L, and Thierfelder C, Weed control in conservation agriculture systems of Zimbabwe: Identifying economical best strategies, Crop Protection, 53, 23- 28, 2013.

Prasad RC, Narasimha TV, Dwarakanath N, Mune Gowda MK, Krishnamurthy MK and $\mathrm{K}$, Integrated weed management in drilled finger millet (Eleusine coracana L. Gaertn.), Mysore Journal Agriculture seience, (25), 13-19, 1991.

Rahangdale CP, Pathak NN and Koshta LD, Impact of bamboo species on growth and yield attributes of kharif crops under agroforestry system in wasteland condition of The Central India, International Journal of Agroforestry and Silviculture 1 (3), 31-36 2014.

Radford PJ, Growth analysis formulae their use and abuse, Crop Science, 7 (3), 171-175, 1967.

Reynolds PE, Simpson JA, Thevathasan NV, Gordon AM, Effect of tree competition on corn and soybean photosynthesis, growth, and yield in a temperate treebased agroforestry intercropping system 
in southern Ontario, Canada, Ecological Engineering, (29), 362-371 2007.

Shukla A, Kumar A, Jha A, Chaturvedi O P, Prasad R, Gupta A, Effects of shade on arbuscular mycorrhizal colonization and growth of crops and tree seedlings in Central India, Agroforestry Systems, 76, 95-109, 2008.

Shanmughavel P, Francis K, Intercropping trials of four crops in bamboo plantations. Journal of Bamboo and Rattan, 1(1), 3-9, 2001.

Singh HP, Batish DR and Kohli RK, Allelopathy interactions and allelochemicals: new possibilities for sustainable weed management, Critical Reviews of Plant Science, 22, 239-311, 2003.

Singh VC, and Arya MPC, Integrated weed management in finger millet (Eleusine coracana), Indian Journal of Agronomy, 44 (3), 571-575, 1999.

Singh, M.K. and Saini, SS. Planting date, mulch, and herbicide rate effects on the growth, yield and physicochemical properties of menthol mint (Mentha arvensis L.), Weed Technology, 22, 691-698, 2008.

SrinivasaRao C, and Lal R, Prasad JVNS, Kodigal AG, Singh R, Jakkula VS, Sahrawat KL, Venkateswarlu B, Sikka AK and Virmani SM, Potential and challenges of rainfed farming in India, Advances in Agronomy, 115-164.

Thapaliyal S, Bali RS, Singh B andTodaria NP, Allelopathic effects of tree of economic importance on germination and growth of food crops, Journal of Herbs, Spices \& Medicinal Plants, 13(4) 2007.

\section{How to cite this article:}

Lokendra Batham, Manoj Kumar Singh, Ashutosh Yadav, Sudhir Das and Sarvesh Kumar. 2020. Effect of Agri-horti Systems and Weed Management Practices on Growth and Yield of Finger Millet (Eleusine coracana L.). Int.J.Curr.Microbiol.App.Sci. 9(07): 1707-1716. doi: https://doi.org/10.20546/ijcmas.2020.907.197 